
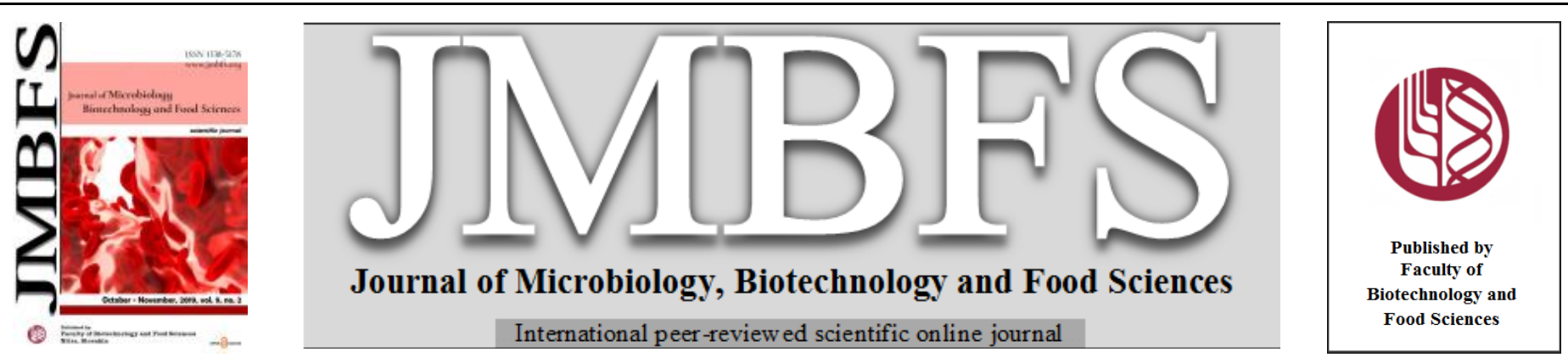

\title{
THE EFFECT OF HONEY VARIETY ON THE QUALITY OF HONEY POWDER
}

\author{
Monika Tomczyk ${ }^{* 1,2}$, Grzegorz Zaguła ${ }^{3}$, Maria Tarapatskyy ${ }^{3}$ Miroslava Kačániová $^{3,4}$, Małgorzata Dżugan $^{1}$
}

\begin{abstract}
Address(es):
${ }^{1}$ Department of Chemistry and Food Toxicology, Institute of Food Technology and Nutrition, University of Rzeszów, Ćwiklińskiej 1a St., 35-601 Rzeszów, Poland. ${ }^{2}$ Faculty of Biotechnology and Food Sciences, Slovak University of Agriculture in Nitra, Tr. A. Hlinku 2, 94976 Nitra, Slovakia.

${ }^{3}$ Department of Bioenergetics and Food Analysis, Institute of Food Technology and Nutrition, University of Rzeszów, Zelwerowicza 4 St., 35-601 Rzeszów, Poland. ${ }^{4}$ Department of Fruit sciences, Viticulture and Enology, Faculty of Horticulture and Landscape Engineering, Slovak University of Agriculture, Tr. A. Hlinku 2, 94976 Nitra, Slovakia.
\end{abstract}

*Corresponding author: mwesolowska@ur.edu.pl

doi: $10.15414 / j m b f s .2020 .9 .5 .949-954$

ARTICLE INFO

Received 1. 4. 2019

Revised 12.11. 2019

Accepted 15. 11. 2019

Published 1. 4. 2020

Regular article

open $\partial_{\text {AcCESS }}$

\section{ABSTRACT}

The conversion of raw honey into powder can increase its usage in food industry but the health properties of obtained powder in relation to chemical composition of honey have been not studied since now. The aim of the study was to check the influence of botanical origin of honey on the quality of honey powder produced by spray drying method. Nine honey samples: honeydew (3), multifloral (3) and acacia (3) were transformed into honey powder using DC1500 dryer (Unimach, China). Analysis of honey powders and comparatively raw honeys covered: physicochemical parameters (moisture content, titratable acidity, $\mathrm{pH}$, electrical conductivity, sugar profile (HPLC) and calorific value), bioactive compounds determination (antioxidant activity (DPPH and FRAP tests), phenolic compounds, mineral composition (ICP-OES) as well as microbiological purity and antibacterial activity. The experiments have shown that honeydew honey powder was characterized by the strongest antioxidant activity and the richest mineral composition, whereas the weakest properties for acacia honey were observed. Moreover, sugar profile of obtained powders was similar to raw honey. It was found that the quality of honey powder was directly dependent on the quality of raw honey.

Keywords: honey, spray drying, antioxidant activity, sugar composition, mineral composition

\section{INTRODUCTION}

Honey belongs to the group of natural sweeteners with a long history of its usage in human nutrition. The main advantage of honey is its extremely rich chemical composition containing antioxidants, vitamins, enzymes as well as macro- and microelements (da Silva et al., 2016). Nevertheless, only small amounts of honey are used on an industrial scale (Jedlińska et al., 2012a). Among honey-based products available on the market the medicaments as syrups strengthening the immune system of children, tablets to relieve inflammation of the throat or herbal teas adding vitality can be found (Jedlińska et al., 2012a). Honey is also a popular component of cosmetics, i.e. shower gels, hair conditioners, face creams and body lotions which soften and enrich the skin with valuable nutrients (Isla $\boldsymbol{e t}$ al., 2013). On the small scale honey is also added to food products such as chocolate bars, candies, nuts, cereals, yogurts, tea, and other beverages.

Limited use of honey in the food industry is mostly related with its sticky consistency, which causes problems with dispensing - honey sticks to the walls of equipment, what causes large losses and problems with cleaning the devices (Jedlińska et al., 2012a). An additional limitation is the natural process of crystallization. Solid honey creates problems during the further handling and processing and requires re-liquefaction which generate additional costs (Conforti et al., 2006). Therefore, there is a need to look for methods which could overcome the problems of storing liquid honey and prevent its crystallization during storage as well as facilitate its dispensing. One of the solution of this problem is to convert the liquid honey into the powder by various drying methods.

Honey in the form of powder would have a good commercial potential in the food and cosmetic industry. The biggest advantages of honey powder are reducing storage space and easier processing and dosing. However, production of honey powder is difficult mainly due to the high content of sugars and organic acids - substances characterized by low glass transition temperature $\left(\mathrm{T}_{\mathrm{g}}\right)$, which is the temperature where the material physically changes from a glassy state to a rubbery state (Nurhadi et al., 2012; Samborska, 2017). Juszczak and Fortuna (2006) reported the $T_{g}$ value of multifloral Polish honey as $-50.7^{\circ} \mathrm{C}$. Other researchers, established lower values: $-37.2^{\circ} \mathrm{C}$ in the case of the Greek multifloral honey (Lazaridou et al., 2004), and between -33.6 and $-51.1^{\circ} \mathrm{C}$ for the Indian nectar honey from different plant species (Ahmed et al., 2007). Drying such material into a powder form is not possible (Gharsallaoui et al., 2007; Adhikari et al., 2007; Hebbar et al., 2008), unless the carrier substance increasing the $\mathrm{T}_{\mathrm{g}}$ is added (Truong et al., 2005).

There are many kinds and different sources of carrier substances used for drying food products i.e. natural gums (Arabic gum, alginates, carrageenans, etc.), proteins (milk or whey proteins, gelatin, etc.), maltodextrins with different dextrose equivalence, waxes and their blends (Truong et al., 2005; Gabas et al., 2007). However, typical carrier materials for drying are starches, corn syrup solids, and maltodextrins. These materials are considered as good carrier agents therefore they exhibit low viscosities at high solids contents and good solubility (Gharsallaoui et al., 2007).

Honey was attempted to be dried by different methods: spray drying, tunnel drying, vacuum drying, drum drying and microwave freeze-drying (Cui et al., 2008). However, the most common method is spray drying (Samborska, 2017). Such technique, apart from removing water (its main purpose) microencapsulates substances susceptible to violent changing environmental conditions, so in consequence obtained product can retain valuable properties (Patel et al., 2009). It is very important in the case of honey which possesses biologically active compounds.

Honey powder is commercially available and on the small scale used in food technology. It was tested that the addition of honey powder to various food products not only improves their taste, but also increase their physical properties. According to Hebbar et al. (2008) the addition of honey powder in dry mixes for cakes and bread improve the flavor, color, aroma, texture and hence keep high quality of the product. Moreover, use of dried honey in certain types of candy, such as honey nougats, sponges and caramels would eliminate the undesirable flavor occurring during high-temperature cooking of raw honey (Hebbar et al., 2008). In the bakery industry, the replacement of 50\% of sucrose by honey powder during baking bread leads to faster and greater firming as well as increasing of loaf volume (Ram, 2011). The usefulness of honey powder in enhancing the oxidative stability of turkey breast was also found (Antony et al., 2000). 
The aim of present study was to produce honey powder by spray drying method in laboratory conditions and to check the influence of used honey variety on chemical and biological properties of obtained powder.

\section{MATERIAL AND METHODS}

\section{Honey powder production}

Nine samples of varietal honeys (honeydew-3, multifloral-3 and acacia3) harvested from local beekeepers in Podkarpackie region in Poland were processed to honey powder by spray drying method. Before the conversion into powder honey samples were stored in a glass containers at room temperature in the dark no more than 3 months. The identification of the botanical origin of each honey was performed by beekeepers based on the availability of nectaring plants.

\section{Preparation solutions for drying}

$30 \% \mathrm{w} / \mathrm{v}$ solutions consisted of honey and carrier substance (maltodextrin lowsaccharificated, NOVAMYL, Poland) in the dry matter mass ratio 1:1 were used for drying according to Samborska and Bieńkowska (2013). As a solvent distilled water was used. All ingredients were mixed using a laboratory homogenizer (Omni Micro Homogenizer no. UHB, Kennesaw, Georgia, USA) during $10 \mathrm{~min}$ to obtain a uniform solution.

\section{Spray drying}

Drying procedure was performed according to the Samborska et al. (2015) with small modifications related to own dryer model (DC1500, Unimach, Shanghai, China). The inlet and outlet air temperature $200^{\circ} \mathrm{C}$ and $80^{\circ} \mathrm{C}$, respectively, with the liquid feed rates $1 \mathrm{~mL} \mathrm{~min}^{-1}$ were applied. Obtained powders were stored in dark in gently closed glass contained until the time of analysis but no more than 3 days. The average recovery of the dry substance contained in the initial solution $(30 \% \mathrm{w} / \mathrm{v})$ was $25 \% \pm 3.7$.

\section{Analytical procedures}

\section{Powder structure analysis}

Microscopic image of the examined honey powders was obtained using an optical microscope (Delta Optical, Poland). Powder sample was applied with a brush onto a glass slide and observed at following magnifications: 100x, 400x, $600 \mathrm{x}$

\section{Physicochemical parameters}

Titratable acidity (TA) was determined according to IHC (2009) for honey. Briefly, $10 \%(\mathrm{w} / \mathrm{v})$ of aqueous honey powder or honey solution was titrated with $0.1 \mathrm{M} \mathrm{NaOH}$ until $\mathrm{pH} 8.3$ in agreement with the $\mathrm{pH}$-meter. TA was expressed as mEq. $100 \mathrm{~g}^{-1}$

The $\mathrm{pH}$ and electrical conductivity (EC) measurements were performed according to IHC (2009) for honey using a digital $\mathrm{pH} /$ conductivitymeter (CP-401, Elmetron, Poland) in $10 \%$ (w/v) of aqueous honey powder and honey solution at $21^{\circ} \mathrm{C}$ (IHC, 2009). EC was expressed as $\mathrm{mS} . \mathrm{cm}^{-1}$.

Moisture content of honey powders was determined using moisture analyzer (Radwag MA50/1.R, Radom, Poland) equipped with infrared heater at $105^{\circ} \mathrm{C}$ until a constant weight and was expresses as $\%$.

\section{Mineral composition}

The concentrations of 9 elements ( $\mathrm{K}, \mathrm{P}, \mathrm{Ca}, \mathrm{Na}, \mathrm{Mg}, \mathrm{Mn}, \mathrm{Zn}, \mathrm{Fe}, \mathrm{Cu}$ ) were determined in honey powders and honeys by optical emission spectrometry with inductively-induced plasma (ICP-OES) using a Thermo iCAP 6500 spectrophotometer (Thermo Fisher Scientific Inc., USA). The samples (about 2 g) of honey powders or honeys were weighed into a plastic falcons, fulfilled until the capacity of $50 \mathrm{~cm}^{3}$ with $20 \% \mathrm{HNO}_{3}(\mathrm{POCH}$, Poland) and directly applied to ICP-OES apparatus (Ioannidou $\boldsymbol{e t}$ al., 2005). The detection threshold obtained for each element was not lower than $0.01 \mathrm{mg} \cdot \mathrm{kg}^{-1}$ (with an assumed detection capacity of the measuring apparatus at a level exceeding $1 \mathrm{ppb}$ ). A curve fit factor for studied elements was above 0.99. All the analyses were done in three independent repetitions for each sample. In order to identify the relevan measurement lines and avoid possible interferences, the method of adding an internal standard was applied. Yttrium and ytterbium ions (at concentrations of 2 mg.dm ${ }^{-3}$ and $5 \mathrm{mg} \cdot \mathrm{dm}^{-3}$, respectively) as internal standard were used. Results were expressed as mg. $100 \mathrm{~g}^{-1}$ of honey powder or honey.

\section{Sugar profile}

Samples of $1 \mathrm{~g}$ of honey powders or honeys were dissolved in $70 \%$ ethanol solution with distilled water in $50 \mathrm{ml}$ volumetric flasks and heated in a water bath at $35-40^{\circ} \mathrm{C}$ for $10 \mathrm{~min}$. Immediately prior to chromatographic analysis, honey solutions were filtered through PTFE $0.22 \mu \mathrm{m}$ filter and diluted 10 fold. Sugar profile was determined according to Rybak-Chmielewska (2007) by high performance liquid chromatography (Thermo Dionex Ultimate 3000) equipped with detector Corona Veo RS (ESA Chelmsford. MA. USA) and autosampler WPS-3000. $10 \mu 1$ of honey powder and honey solution was injected into the column Shodex Asahipak NH2P-504E (4.6 x $250 \mathrm{~mm}$ ). The separation was conducted at a temperature of $55^{\circ} \mathrm{C}$ with the mobile phase acetonitrile:water $78: 22(\mathrm{v} / \mathrm{v})$, at a flow rate of $1 \mathrm{~mL} \cdot \mathrm{min}^{-1}$. The identification of sugars in honey samples was done by comparing retention times of individual sugars standard in the reference vs. tested solution. The content of the following carbohydrates: fructose, glucose, sucrose, maltose, melezitose, and trehalose obtained from Sigma (Saint Louis, Missouri, USA) was calculated based on the externa standard curve. The contents of tested carbohydrates were expressed as g per 100 $\mathrm{g}$ of honey powder or honey.

\section{Calorific value}

The calorific value of honey powders and honeys was identified by LECO AC 500 calorimeter (oxygen bomb system) in accordance with PN-EN ISO 18125:2017-07 (2017).

\section{Antioxidant activity}

\section{DPPH assay}

The antioxidant activity of honey powders and honey was assessed using DPPH assay according to Gorjanovic et al. (2013). The $0.2 \mathrm{~mL}$ of $10 \%$ (w/v) aqueous honey powders or $5 \%(\mathrm{w} / \mathrm{v})$ aqueous honey solutions were mixed with $1.8 \mathrm{~mL}$ of methanol DPPH $(0.1 \mathrm{mM})$ solution and left to stand in the dark at room temperature for $60 \mathrm{~min}$. After incubation, the absorbance of the reaction mixture $\left(\mathrm{A}_{\mathrm{S}}\right)$ and blank $\left(\mathrm{A}_{0}\right)$ was measured at $517 \mathrm{~nm}$ against methanol. The DPPH scavenging activity was calculated using the following equation: DPPH $\%=\left[\left(\mathrm{A}_{0}-\mathrm{A}_{\mathrm{S}}\right) / \mathrm{A}_{0}\right] \times 100$

\section{FRAP test}

The FRAP assay was carried according to Bertoncelj et al. (2007). A 10\% (w/v) of aqueous honey powders or $5 \%(\mathrm{w} / \mathrm{v})$ aqueous honey solutions were used. For the calibration, $0.1 \mathrm{mM}$ Trolox solution $(15-200 \mathrm{nmol})$ was used and the results were expressed as $\mu \mathrm{mol}$ of Trolox equivalents (TE) per $100 \mathrm{~g}$ of honey powder or honey ( $\mu \mathrm{mol} \mathrm{TE} .100 \mathrm{~g}^{-1}$ of sample).

\section{Total phenolic compounds (TPC) content}

The Folin-Ciocalteu method modified by Beretta et al. (2005) was used to determine total phenolic compounds content. A $10 \%$ (w/v) of aqueous honey powders or $5 \%(\mathrm{w} / \mathrm{v})$ aqueous honey solutions were used. Gallic acid $(0-200$ $\mathrm{mg} \cdot \mathrm{mL}^{-1}$ ) was used as a standard to obtain the calibration curve. Total phenolic compounds content was expressed as $\mathrm{mg}$ of gallic acid equivalent per $100 \mathrm{~g}$ of honey powder or honey (mg.GAE $100 \mathrm{~g}^{-1}$ of sample).

\section{Antibacterial activity assay}

Antibacterial activity was determined according to Kačániová et al. (2012). Aqueous honey powder solutions were prepared in concentration 12.5, 25 and $50 \% \mathrm{w} / \mathrm{v}$. Samples were screened for their antimicrobial activity, according to the agar well diffusion method against the following reference strains: Gram negative (1) Enterococcus faecalis, (2) Clostridium perfringens (3) Staphylococcus aureus; Gram positive (4) Haemeophilus influenzae (5) Yersinia enterocolitica (6) Salmonella enterica; Yeasts (7) Candida tropicalis (8) Candida albicans (9) Candida glabrata. The bacterial strains were purchased from the Czech Collection of Microorganisms (CCM). Suspensions of the microorganisms were prepared to contain approximately $10^{8} \mathrm{cfu}_{\mathrm{ml}} \mathrm{m}^{-1}$ and then $100 \mu \mathrm{l}$ of these suspensions were inoculated in plates containing agar medium.

All the above microorganisms were grown in Muller Hinton broth (BiomarkTM, Pune, India) at $30^{\circ} \mathrm{C}$ for $24 \mathrm{~h}$. In the solidified Muller Hinton agar (BiomarkTM, Pune, India) wells with a diameter of $0.5 \mathrm{~cm}$ were cut and filled with $1 \mathrm{ml}$ of honey powder solutions. Samples were incubated at $30^{\circ} \mathrm{C}$ for $24 \mathrm{~h}$. Antibacteria activity was assessed by measuring the diameter (in $\mathrm{mm}$ ) of the inhibition zones surrounding the wells.

\section{Total number of microorganisms}

Determination of the total number of microorganisms on a solid substrate using plate diluting method according to Kačániová et al. (2007) was applied. The Tryptic Glucose Yeast Agar (GTK) (Biolife, Italy) for total count of bacteria and Malt Extract Agar (MEA) (Biolife, Italy) for cultivation yeasts and molds were inoculated with $1 \mathrm{ml}$ of honey powder solution $(1 \% \mathrm{w} / \mathrm{v})$ by flushing on the surface of solid substrates in Petri dishes. After incubation at $30^{\circ} \mathrm{C}$ during $36 \mathrm{~h}$ 
formed colonies were counted. The number of formed colonies corresponding to the number of living cells in the sample were expressed as cfu. $\mathrm{kg}^{-1}$.

\section{Statistical analysis.}

All results were expressed as the means $\pm \mathrm{SD}(\mathrm{n}=3)$. For statistical analysis, one-way analysis of variance (ANOVA) was applied followed by post doc Tukey's test. The correlation between studied parameters were made using Spearman's correlation analysis. Values of $\mathrm{P}<0.05$ were considered to indicate statistically significant differences. In order to find similarities between honey powders and raw honeys cluster analysis was performed based on the average value of each variety, using the complete linkage as a connection method and the Euclidean distance as a bond distance. All statistical analyses were performed with the Statistica 13.0 software.

\section{RESULTS AND DISCUSSION}

For honey powder production 3 different honey types originated from 3 different apiaries variable in their physicochemical properties and antioxidant activity were used (Table 1). According to the standard limits established by EU Directive (Council Directive EU, 2001) based on their physicochemical parameters all tested honeys were evaluated as good quality products, not exceeding the applicable standards. Moreover, in terms of other indicators, not included in the regulations, their antioxidant activity and mineral content was specific for honeys produced in Podkarpackie region (Wesołowska and Dżugan, 2017; Dżugan et al., 2017; Dżugan et al., 2018). Due to our earlier study showed that local hones differ in microbiological quality (Wesolowska $\boldsymbol{e t}$ al. 2014), for present study, samples characterized by different microbiological contamination were chosen in order to test the decontamination effect of spray drying method. Among studied samples, the honeydew honey was the most valuable due to high mineral content and strong antioxidant activity. However, it was also the most contaminated with yeast and bacteria (Table 1).

Table 1 Physicochemical properties and antioxidant activity of tested honeys

\begin{tabular}{|c|c|c|c|}
\hline $\begin{array}{l}\text { Sample/ } \\
\text { parameter }\end{array}$ & $\begin{array}{l}\text { Honeydew honey } \\
(\mathrm{n}=3)\end{array}$ & $\begin{array}{l}\text { Multifloral honey } \\
(\mathrm{n}=3)\end{array}$ & $\begin{array}{l}\text { Acacia honey } \\
\quad(\mathrm{n}=3)\end{array}$ \\
\hline \multicolumn{4}{|c|}{ Physicochemical properties } \\
\hline Moisture [\%] & $17.65 \pm 1.70$ & $19.55 \pm 3.49$ & $17.80 \pm 2.85$ \\
\hline Free acidity $\left[\mathrm{mEq} \cdot 100 \mathrm{~g}^{-1}\right]$ & $3.67 \pm 0.53$ & $3.25 \pm 1.77$ & $3.05 \pm 0.37$ \\
\hline $\mathrm{pH}$ & $4.39 \pm 0.19$ & $3.64 \pm 0.23$ & $3.75 \pm 0.49$ \\
\hline Conductivity $\left[\mathrm{mS} . \mathrm{cm}^{-1}\right]$ & $0.972 \pm 0.12$ & $0.261 \pm 0.17$ & $0.577 \pm 0.34$ \\
\hline \multicolumn{4}{|c|}{ Mineral composition $\left[\mathrm{mg} .100 \mathrm{~g}^{-1}\right]$} \\
\hline$\overline{\mathrm{K}}$ & $227.7 \pm 62.51^{\mathrm{a}}$ & $144.84 \pm 17.73$ & $122.47 \pm 67.53^{\mathrm{b}}$ \\
\hline $\mathrm{P}$ & $21.34 \pm 2.74$ & $19.53 \pm 3.15$ & $13.72 \pm 1.46$ \\
\hline $\mathrm{Ca}$ & $11.22 \pm 1.78$ & $8.17 \pm 4.28$ & $10.11 \pm 1.37$ \\
\hline $\mathrm{Mg}$ & $5.40 \pm 0.92$ & $4.04 \pm 1.81$ & $3.49 \pm 0.96$ \\
\hline $\mathrm{Na}$ & $2.38 \pm 0.78$ & $2.06 \pm 0.51$ & $1.79 \pm 0.63$ \\
\hline $\mathrm{Mn}$ & $0.31 \pm 0.14$ & $0.57 \pm 0.11$ & $0.24 \pm 0.15$ \\
\hline $\mathrm{Fe}$ & $0.28 \pm 0.07$ & $0.13 \pm 0.05$ & $0.19 \pm 0.09$ \\
\hline $\mathrm{Zn}$ & $0.10 \pm 0.02$ & $0.15 \pm 0.04$ & $0.12 \pm 0.05$ \\
\hline $\mathrm{Cu}$ & $0.11 \pm 0.04$ & $0.03 \pm 0.01$ & $0.02 \pm 0.01$ \\
\hline \multicolumn{4}{|c|}{ Sugar composition $\left[{\left.\mathrm{g} .100 \mathrm{~g}^{-1}\right]}^{-1}\right.$} \\
\hline Fructose & $34.88 \pm 1.31$ & $38.09 \pm 3.75$ & $37.37 \pm 2.58$ \\
\hline Glucose & $30.65 \pm 1.62$ & $32.54 \pm 2.43$ & $33.17 \pm 1.45$ \\
\hline Sucrose & $5.24 \pm 1.07$ & $4.10 \pm 0.64$ & $3.91 \pm 0.78$ \\
\hline Maltose & $1.16 \pm 0.56$ & $0.61 \pm 0.32$ & n.d. \\
\hline Trehalose & n.d. & n.d. & n.d. \\
\hline Melezitose & $0.62 \pm 0.44$ & n.d. & n.d. \\
\hline Calorific value [kcal. $\left.100 \mathrm{~g}^{-1}\right]$ & $335.41 \pm 2.36$ & $328.32 \pm 1.98$ & $331.87 \pm 3.21$ \\
\hline \multicolumn{4}{|c|}{ Antioxidant activity } \\
\hline $\mathrm{DPPH}^{*}[\%$ inhibition $]$ & $56.86 \pm 3.45$ & $45.65 \pm 16.43$ & $21.55 \pm 10.31$ \\
\hline FRAP $\left[\mu \mathrm{mol}\right.$ TE. $\left.100 \mathrm{~g}^{-1}\right]$ & $243.07 \pm 76.52$ & $171.64 \pm 68.32$ & $126.79 \pm 38.62$ \\
\hline TPC [mg GAE. $\left.100 \mathrm{~g}^{-1}\right]$ & $81.35 \pm 20.13$ & $54.96 \pm 23.31$ & $46.76 \pm 18.98$ \\
\hline \multicolumn{4}{|c|}{$\begin{array}{l}\text { Microbiological purity } \\
\end{array}$} \\
\hline Number of bacteria $\left[\mathrm{cfu} \mathrm{kg}^{-1}\right]$ & 2980 in $1 / 3$ & 40 in $1 / 3$ & not found \\
\hline Number of yeasts [cfu kg-1] & 330 and 440 in $2 / 3$ & 200 and 260 in $2 / 3$ & Not found \\
\hline
\end{tabular}

${ }^{\mathrm{a}, \mathrm{b}}$ statistical differences $(\mathrm{p}<0.05)$ in the line

In order to check the influence of honey variety on physical and chemical properties of honey powders, tested samples of honey were dehydrated by laboratory spray dryer. Microscopic analysis of obtained honey powders proved their round regular structure, however analysis indicated some differences between the size of particles depending on the used type of honey. The multifloral honey powder had the biggest $(17.2-48.1 \mu \mathrm{m})$ while acacia honey powder the smallest $(10.6-26.7 \mu \mathrm{m})$ size of particles. Similar observation was found by Samborska and Czelejewska (2014) who tested the particle size of multifloral honey powder with addition of Arabic gum at the average level $6.2 \mu \mathrm{m}$, while in the case of rape honey powder it was $8.4 \mu \mathrm{m}$. In the present study beside of round regular crystals some of the particles in every sample had an irregular structure which can be caused by a slower evaporation rate in some particles as well as other factors such as atomization and feed rate (Anandharamakrishnan and Ishwarya, 2015). However, most of the particles were smooth and more or less dispersed. Jedlińska et al. (2012b) proved that spray-dried honey, with the use of maltodextrin as a carrier, was characterized by good flow ability and medium cohesion as well as instant solubility in water. The solubility of obtained honey powder was checked in the range $0.1-1.5 \mathrm{~g} \cdot \mathrm{mL}^{-1}$ of water. The best solubility of powders regardless of the type of honey in the amount $0.5 \mathrm{~g} . \mathrm{mL}^{-1}$ was observed.

Results indicated that the variety of honey used for honey powder production influenced both their physicochemical properties and biological activity (Table 2). It is known that moisture content of spray dried powders can be affected by the feed flow rate, the inlet temperature as well as the amount and type of added drying agent (Shi et al., 2013; Anandharamakrishnan and Ishwarya, 2015). In this aspect, the moisture of examined honey powder dried with addition of maltodextrin was lower (about $3 \%$ ) than obtained for spray dried honey powders with resistant starch addition as a drying agent (3.83 - 5.53\%) (Ram, 2011). In general, the physicochemica parameters of obtained honey powders strongly reflected to the raw honey properties. Free acidity as well as $\mathrm{pH}$ values of tested powders was the lowest in acacia honey powder while the highest in honeydew honey powder, similarly as for raw honey. The highest conductivity in honeydew honey powders was detected, while the lowest in the powder of acacia honey, however differences were not statistically significant $(\mathrm{p}>0.05)$. These values were lower as in raw honey (Table 1) 
Table 2 Physicochemical properties and antioxidant activity of tested honey powders obtained by spray drying.

\begin{tabular}{|c|c|c|c|}
\hline $\begin{array}{l}\text { Sample/ } \\
\text { parameter }\end{array}$ & $\begin{array}{c}\text { Honeydew powder } \\
(\mathrm{n}=3)\end{array}$ & $\begin{array}{c}\text { Multifloral powder } \\
(\mathrm{n}=3)\end{array}$ & $\begin{array}{c}\text { Acacia powder } \\
(\mathrm{n}=3)\end{array}$ \\
\hline \multicolumn{4}{|c|}{ Physicochemical properties } \\
\hline Moisture [\%] & $2.88 \pm 0.01$ & $3.56 \pm 0.16$ & $3.04 \pm 0.18$ \\
\hline Free acidity* [mEq. $\left.100 \mathrm{~g}^{-1}\right]$ & $3.75 \pm 0.78$ & $3.60 \pm 0.28$ & $3.25 \pm 1.34$ \\
\hline $\mathrm{pH}^{*}$ & $4.92 \pm 0.32$ & $4.50 \pm 0.12$ & $4.77 \pm 0.54$ \\
\hline Conductivity* $\left[\mathrm{mS} . \mathrm{cm}^{-1}\right]$ & $0.125 \pm 0.03$ & $0.096 \pm 0.01$ & $0.064 \pm 0.01$ \\
\hline \multicolumn{4}{|c|}{ Mineral composition $\left[\mathrm{mg} 100 \mathrm{~g}^{-1}\right]$} \\
\hline $\mathrm{K}$ & $136.55 \pm 30.80^{\mathrm{a}}$ & $97.27 \pm 14.98$ & $43.94 \pm 12.73^{\mathrm{b}}$ \\
\hline $\mathrm{P}$ & $51.89 \pm 3.86$ & $47.61 \pm 2.51$ & $44.88 \pm 2.11$ \\
\hline $\mathrm{Ca}$ & $34.36 \pm 1.19$ & $38.65 \pm 3.28$ & $35.19 \pm 1.57$ \\
\hline $\mathrm{Mg}$ & $9.37 \pm 1.11$ & $8.40 \pm 0.59$ & $7.15 \pm 0.74$ \\
\hline $\mathrm{Na}$ & $4.80 \pm 0.97$ & $4.14 \pm 0.22$ & $3.95 \pm 1.13$ \\
\hline $\mathrm{Mn}$ & $0.39 \pm 0.10$ & $0.56 \pm 0.08$ & $0.28 \pm 0.02$ \\
\hline $\mathrm{Fe}$ & $0.45 \pm 0.03$ & $0.41 \pm 0.02$ & $0.29 \pm 0.07$ \\
\hline $\mathrm{Zn}$ & $0.06 \pm 0.05$ & $0.17 \pm 0.10$ & $0.04 \pm 0.02$ \\
\hline $\mathrm{Cu}$ & $0.09 \pm 0.01$ & $0.08 \pm 0.02$ & $0.07 \pm 0.04$ \\
\hline \multicolumn{4}{|c|}{ Sugar composition $\left[{\left.\mathrm{g} 100 \mathrm{~g}^{-1}\right]}^{-1}\right.$} \\
\hline Fructose & $35.78 \pm 3.29$ & $39.50 \pm 1.21$ & $39.72 \pm 0.62$ \\
\hline Glucose & $27.27 \pm 0.89$ & $28.59 \pm 2.40$ & $31.83 \pm 0.04$ \\
\hline Sucrose & $3.39 \pm 0.18$ & $2.19 \pm 1.05$ & $3.27 \pm 1.42$ \\
\hline Maltose & $2.70 \pm 0.11$ & $2.02 \pm 0.42$ & $2.06 \pm 1.36$ \\
\hline Trehalose & $1.30 \pm 0.02$ & $0.34 \pm 0.21$ & $0.24 \pm 0.08$ \\
\hline Melezitose & $0.18 \pm 0.04$ & n.d. & n.d. \\
\hline Calorific value [kcal. $\left.100 \mathrm{~g}^{-1}\right]$ & $376.92 \pm 1.40$ & $369.73 \pm 3.19$ & $375.96 \pm 1.85$ \\
\hline \multicolumn{4}{|c|}{ Antioxidant activity } \\
\hline DPPH* [\% inhibition] & $47.12 \pm 1.17$ & $29.22 \pm 20.85$ & $11.37 \pm 5.81$ \\
\hline FRAP $\left[\mu \mathrm{mol}\right.$ TE. $\left.100 \mathrm{~g}^{-1}\right]$ & $182.67 \pm 33.62$ & $124.93 \pm 46.05$ & $59.04 \pm 15.45$ \\
\hline TPC [mg GAE. $\left.100 \mathrm{~g}^{-1}\right]$ & $50.86 \pm 1.57$ & $48.26 \pm 13.44$ & $29.58 \pm 3.95$ \\
\hline \multicolumn{4}{|c|}{ Microbiological purity } \\
\hline Number of bacteria [cfu.kg $\left.{ }^{-1}\right]$ & 840 in $1 / 3$ & not found & not found \\
\hline Number of yeasts $\left[\mathrm{cfu} \cdot \mathrm{kg}^{-1}\right]$ & 200 in $1 / 3$ & not found & not found \\
\hline
\end{tabular}

The predominant element in honey powders, tested by ICP-OES method, was K as it occurs in raw honey. The content of the rest tested macroelements decreased in the following order: $\mathrm{P}>\mathrm{Ca}>\mathrm{Mg}>\mathrm{Na}$. Microelements (as $\mathrm{Mn}, \mathrm{Fe}, \mathrm{Zn}$ and $\mathrm{Cu}$ ) in concentrations less than $0.6 \mathrm{mg} .100 \mathrm{~g}^{-1}$ were detected. Honeydew honey powders were the richest in $\mathrm{K}(\mathrm{p}<0.05), \mathrm{P}, \mathrm{Mg}$ and $\mathrm{Na}$ while the lowest levels of such elements in acacia honey powders were found. The proportions of minerals in honey powder as compared to the raw honey in most cases were maintained. However the levels of $\mathrm{P}, \mathrm{Ca}, \mathrm{Mg}$ and $\mathrm{Na}$ were higher in honey powder as compared to raw honey (Table 1) due to its introduction with maltodextrin. The concentrations of minerals in maltodextrin in mg.100g ${ }^{1}$ were as follows: $\mathrm{K}$ (12.60), $\mathrm{P}$ (62.53), Ca (55.66), Mg (8.94), Na (7.27), Mn (0.17), Fe (0.13), $\mathrm{Zn}(0.07)$ and $\mathrm{Cu}(0.03)$. Increased levels of macroelements in maltodextrin as compared to raw honeys influenced the mineral composition of honey powders.

The sugar profile in tested honey powders analyzed by HPLC method also reflected to raw honeys. The sum of fructose and glucose content in honey powders was between 63 and $71 \mathrm{~g} .100 \mathrm{~g}^{-1}$ while in raw honeys between 66 and 71 g. $100 \mathrm{~g}^{-1}$. However, fructose to glucose ratio $(\mathrm{F} / \mathrm{G})$ in honey powders ranged from 1.24 to 1.38 and was higher as compared to raw honeys (from 1.11 to 1.17 ). The lowest $\mathrm{F} / \mathrm{G}$ ratio was found in both acacia products in powder and raw honey. It can be caused by both addition of reducing sugars with low saccharificated maltodextrin and/or transformation of sugars during processing in dryer. Similarly, maltose was found in honey powders in higher (for about $57-100 \%$ ) levels as compared to raw honey due to its introduction with maltodextrin (Fortuna and Sobolewska, 2000). The same for trehalose which was introduced into honey powder in $100 \%$ from maltodextrin (in raw honey was not detected). A melezitose which is a sugar indicator of honeydew honey (RybakChmielewska, 2007) was also found in honeydew honey powder. Results are in agreement with Ram (2011) who determined sugar profile in honey powders made from multifloral honeys originated from Louisiana

The differences in sugar content reflected to the calorific value of obtained honey powders which was slightly higher for honeydew honey and acacia powders as compared to multifloral honey powder. However the calorific value of obtained honey powders varied slightly between honey variety as it is present in raw honey (Buba et al., 2013). Due to added maltodextrin to honey powders, its calorific value was higher than in raw honey for about $20 \%$.

All honey powders preserved antioxidant activity of raw honey which was found by both FRAP and DPPH tests (Table 2). Honey powders obtained from honeydew honey exhibited the best activity to neutralize DPPH radicals indicating the strongest antioxidant activity while acacia honey powder showed the lowest antioxidant properties. Reducing antioxidant power measured by FRAP test was also the highest in honeydew honey powder $\left(182.67 \mu \mathrm{mol}\right.$ TE. $\left.100 \mathrm{~g}^{-1}\right)$ which was higher by $32 \%$ and $68 \%$ as compared to multifloral and acacia honey powders, respectively. The same parameter measured for raw honeys was slightly higher (Table 1) and obtained results were in agreement with other authors (Gheldof and Engeseth, 2002; Kesic et al., 2009; Dżugan et al., 2018). Results indicated that honey powder produced from highly active honey possess antioxidant activity comparable to raw honey with weak biological value. The differences in total phenolic compounds content in honey powder produced from different varieties of honey measured by Folin-Ciocalteu method were smaller than in antioxidan activity (Table 2). Multifloral and honeydew honey powders had comparable levels of phenolics compounds (about $49.5 \mathrm{mg} \mathrm{GAE} 100 \mathrm{~g}^{-1}$ ) while in acacia honey powders about $20 \%$ lower amount of this compounds was tested. The total phenolics compounds content tested by Stagos et al. (2018) in Greek multifloral honey powders obtained by freeze drying method were comparable to present study and ranged 40 and $52 \mathrm{mg}$ GAE. $100 \mathrm{~g}^{-1}$. Higher levels of this compounds authors found in herb-honeys powders $\left(72 \mathrm{mg} \mathrm{GAE} 100 \mathrm{~g}^{-1}\right.$ for oregano and 67 mg GAE. $100 \mathrm{~g}^{-1}$ for mint honey). The total phenolics compounds content in raw honeys was slightly higher as compared to honey powders (Table 1), and were in agreement with Mellen et al. (2015). It indicates that spray drying of honey allows to retain majority of the components responsible for the antioxidant properties. According to Stagos et al. (2018) the loose of phenolic compounds in honey converted into powder by freeze-drying method was about $21-32 \%$

Honey is known to exhibit protective effect against most of bacteria and yeasts (Kačániová et al., 2012; Almasaudi et al., 2017; Szweda, 2017; Stagos et al., 2018) thus we checked the antimicrobial property of obtained powders. However, we do not confirmed antibacterial action of honey powders against tested microorganisms (six bacteria species and two yeasts), at none of the tested samples an inhibition zone of microorganisms growth occurred. It is caused by both losses of honey antioxidant termolabile componets and $50 \%$ share of maltodextrin in in final product.

In order to check honey powder safety and its possibility to use in food production, microbiological purity was checked. Moreover, the influence of raw honey microbiological contamination on the microbiological impurity of honey powder was also tested. Among used nine raw honey samples only in two the presence of bacteria was determined, $2980 \mathrm{cfu}^{-\mathrm{kg}^{-1}}$ in one honeydew honey and $40 \mathrm{cfu} . \mathrm{kg}^{-1}$ in one multifloral honey. In these cases we observed strong reduction of bacteria number during spray drying, 3 times lower for the honeydew honey powder and complete decontamination for multifloral honey powder. The remaining honey powders were mostly free from microbiological 
contamination. Yeast and molds were detected in 4 samples of raw honey at a number of 200 - $440 \mathrm{cfu} \cdot \mathrm{kg}^{-1}$. Only one honey powder (produced from the most contaminated honey) was contaminated with yeasts and molds with number 200 cfu. $\mathrm{kg}^{-1}$. It indicates that application of spray drying can decrease the number of microorganisms present in honey and does not introduce additional contamination during the process. However, the efficiency of microbiological removal is dependent on initial microbiological quality of the used honey.

Statistical analysis based on Sperman's correlation rank proved that the quality of honey powder is directly related to the quality of honey used for honey powder production. The $\mathrm{r}$ values calculated for all tested physicochemical parameters between honey powders and honeys ranged from 0.351 to 0.612 . The significantly high Sperman's correlation rank between honey and honey powder antioxidant activity was found, in detail $\mathrm{r}=0.748$ for DPPH, 0.901 for FRAP and 0.875 for TPC tests. The relation between honey and honey powder properties was also confirmed by cluster analysis (Figure 1). Although the distance between honeys were greater than between honey powders, for both the largest differences for honeydew and acacia honey were observed (bond distance 168.24 and 159.85, respectively). The biggest differences for honeydew honey and obtained honeydew honey powder (bond distance 123.85), while the lowest for multiflora honey and honey powder (bond distance 82.34) was found. Moreover, powder from honeydew honey showed similar properties to raw multifloral honey (bond distance 47.94) and multifloral honey powder exhibited similar properties to raw acacia honey (bond distance 54.12).

Such results indicate that after conversion honey into powder form, major part of biologically active substances are kept. It proves that honey powder produced from high quality honey can be its substitute of slightly lower quality. Thus, findings suggested that spray drying method was effective for transforming honey to powder and can be used for different purposes in order to exploit the beneficial effects of honey on human health.

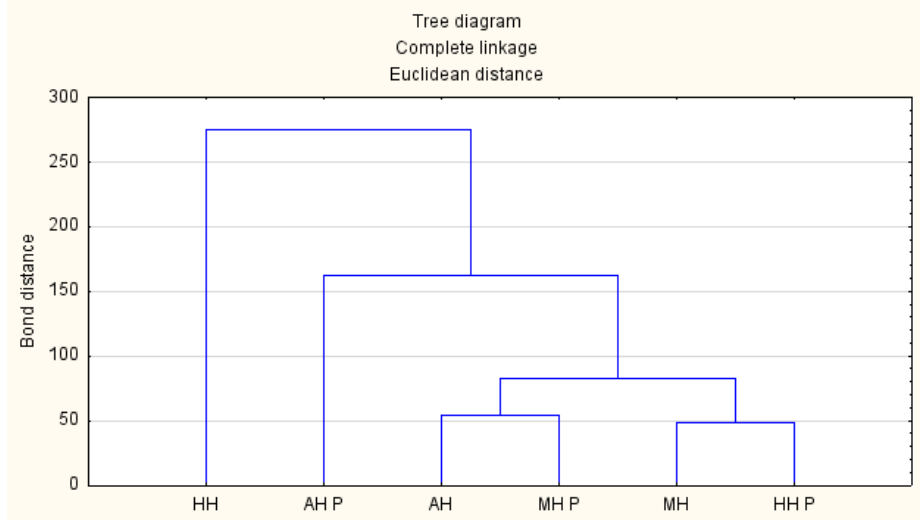

Figure 1 Tree diagram based on average values of tested parameters for honey powders and raw honeys (complete linkage, Euclidean distance)

Description: HH-honeydew honey, AH P-acacia honey powder, AH-acacia honey, MH P-multifloral honey powder, MH-multifloral honey, HH P-honeydew honey powder

\section{CONCLUSION}

Experiments have shown that it is possible to produce a honey-based powder by spray drying method with good physical properties which will be easy to dosing and further processing. It was tested that the high temperature of drying $\left(200^{\circ} \mathrm{C}\right)$ does not fundamentally change the chemical composition of the honey in the form of powder, however partial degradation of the biological activity (antioxidant, microbiological quality) was observed. Moreover, it was proved that physical and chemical properties of obtained powders were honey varietydependent and in general other parameters of honey powders were similar to raw honey. However, the higher quality of raw honey subjected to drying is, the more valuable honey powder is produced. Despite the decrease of antibacterial activity, the use of spray drying resulted in obtaining a microbiologically pure product useful for food industry for convenience food.

Acknowledgments: The work was financially supported by research project no. $\mathrm{PB} / \mathrm{KChTŻ/2018.}$

\section{REFERENCES}

Adhikari, B., Howes, T., Shrestha, A. K., \& Bhandari, B. R. (2007). Development of stickiness of whey protein isolate and lactose droplets during convective drying. Chemical Engineering and Processing, 46(5), 420-428. https://doi.org/10.1016/j.cep.2006.07.014

Ahmed, J., Prabhu, S. T., Raghavan, G. S. T., \& Ngadi, M. (2007). Physicochemical, rheological, calorimetric and dielectric behavior of selected Indian honeys. Journal of Food Engineering, 79(4), 1207-1213. https://doi.org/10.1016/j.jfoodeng.2006.04.048
Almasaudi, S. B., Al-Nahari, A. A. M., El-Ghany, S. M. A., Barbour, E., Al Muhayawi, S.M., Al-Jaouni, ... \& Harakeh, S. (2017). Antimicrobial effect of different types of honey on Staphylococcus aureus. Saudi Journal of Biological Sciences, 24(6), 1255-1261. https://doi.org/10.1016/j.sjbs.2016.08.007

Anandharamakrishnan, C., Padma Ishwarya, S. (2015). Spray drying techniques for food ingredient encapsulation. John Wiley and Son Ltd. IFT Press, Chicago. Antony, S., Rieck, J. R., \& Dawson, P. L. (2000). Effect of dry honey on oxidation in turkey breast meat. Poultry Science, 79(12), 1846-1850. https://doi.org/10.1093/ps/79.12.1846

Beretta, G., Granata, P., Ferrero, M., \& Faccino, F. M. (2005). Standardization of antioxidant properties of honey by a combination of spectrophotometric/fluorimetric assays and chemometrics. Analytica Chimica Acta, 533(2), 185-191. https://doi.org/10.1016/j.aca.2004.11.010.

Bertoncelj, J., Doberšek, U., Jamnik, M., \& Golob, T. (2007). Evaluation of the phenolic content, antioxidant activity and colour of Slovenian honey. Food Chemistry, 105(2), 822-828. https://doi.org/10.1016/j.foodchem.2007.01.060.

Buba, F., Gidado, A., \& Shugaba, A. (2013). Analysis of Biochemical Composition of Honey Samples from North-East Nigeria. Biochemistry and Analytical Biochemistry, 2(3), Article no.:139. https://doi.org/10.4172/2161 1009.1000139

Conforti, P. A., Lupano, C. E., Malacalza, N. H., Arias, V., \& Castells, C. B. (2006). Crystallization of honey at $-20^{\circ} \mathrm{C}$. International Journal of Food Properties, 9(1), 99-107. https://doi.org/10.1080/10942910500473962

Council Directive EU, 2001. Council Directive 2001/110/EC of 20 December 2001 relating to honey. Official Journal of the European Communities 2002 L10:47-52.

Cui, Z. W., Sun, L. J., Chen, W., Sun, D. W. (2008). Preparation of dry honey by microwave-vacuum drying. Journal of Food Engineering, 84(4), 582-590. https://doi.org/10.1016/j.jfoodeng.2007.06.027

Da Silva, P. M., Gauche, C., Gonzaga, L. V., Costa, A. C. O., \& Fett, R. (2016) Honey: Chemical composition, stability and authenticity. Food Chemistry, 196(1), 309-323. doi: http://dx.doi.org/10.1016/i.foodchem.2015.09.051

Dżugan, M., Tomczyk, M., Sowa, P., \& Grabek-Lejko, D. (2018). Antioxidant Activity as Biomarker of Honey Variety. Molecules, 23, 2069 https://doi.org/10.3390/molecules23082069

Dżugan, M., Zaguła, G., Wesołowska, M., Sowa, P., \& Puchalski, Cz. (2017) Levels of toxic and essential metals in varietal honeys from Podkarpacie. Journal of Elementology, 22(3), https://doi.org/10.5601/jelem.2016.21.4.1298

Fortuna, T., \& Sobolewska, J. (2000). Maltodekstryny i ich wykorzystanie w przemyśle spożywczym. Maltodextrins and their application in food industry. Żywność., 2(23), 100-109.

Gabas, A. L., Telis, V. R. N., Sobral, P. J. A., \& Telis-Romero, J. (2007). Effect of maltodextrin and arabic gum in water vapor sorption thermodynamic properties of vacuum dried pineapple pulp powder. Journal of Food Engineering, 82(2), 246-252. https://doi.org/10.1016/j.jfoodeng.2007.02.029

Gharsallaoui, A., Roudaut, G., Chambin, O., Voilley, A., \& Saurel, R. (2007) Applications of spray-drying in microencapsulation of food ingredients: An overview. Food Research International, 40(9), 1107-1121. https://doi.org/10.1016/j.foodres.2007.07.004

Gheldof, N., \& Engeseth, N. J. (2002). Antioxidant capacity of honeys from various floral sources based on the determination of oxygen radical absorbance capacity and inhibition of in vitro lipoprotein oxidation in human serum samples. Journal of Agricultural and Food Chemistry, 50(10), 3050-3055 https://doi.org/10.1021/jf0114637.

Gorjanovic, S. Z., Alvarez-Suarez, J. M., Novakovic, M. M., Pastor, F. T., Pezo, L., Battino, M., \& Suznjevic, D. Z. (2013). Comparative analysis of antioxidan activity of honey of different floral sources using recently developed polarographic and various spectrophotometric assays. Journal of Food $\begin{array}{llll}\text { Composition } \quad \text { and } & \text { Analysis, } & 30(1), 18\end{array}$ https://doi.org/10.1016/j.jfca.2012.12.004.

Hebbar, H. U., Rastogi, N. K., \& Subramanian, R. (2008). Properties of dried and intermediate moisture honey products: a review. International Journal of Food Properties, 11(4), 804-819. https://doi.org/10.1080/10942910701624736.

IHC, 2009. Harmonised Methods of The International Honey Commission (Available on: http://www.bee-hexagon.net/en/network.htm, access: 15.09.2018) Ioannidou, M. D., Zachariadis, G. A., Anthemidis, A. N., \& Stratis, J. A. (2005) Direct determination of toxic trace metals in honey and sugars using inductively coupled plasma atomic emission spectrometry. Talanta 65, 92-97. https://doi.org/10.1016/j.talanta.2004.05.018

Isla, M., Cordero, A., Díaz, L., Pérez-Pérez, E. M., \& Vit, P. (2013). Cosmetic properties of honey. 1. Antioxidant activity. In Vit P \& Roubik DW, eds Stingless bees process honey and pollen in cerumen pots. Facultad de Farmacia y Bioanálisis, Universidad de Los Andes; Mérida, Venezuela.

Jedlińska, A., Samborska, K., \& Witrowa-Rajchert, D. (2012a). Aspekty techniczno-technologiczne suszenia miodu (Technical and technological aspects of drying honey). Nauki Inżynierskie i Technologie, 2(5), 35-43. (in Polish)

Jedlińska, A., Samborska, K., \& Witrowa-Rajchert, D. (2012b). Właściwości fizyczne proszków na bazie miodu pszczelego otrzymanych metodą suszenia rozpyłowego i sublimacyjnego (Physical properties of powders based on bee 
honey obtained by spray drying and freeze drying methods). Acta Agrophysica, 19(3), 563-574. (in Polish)

JUSZCZAK, L., \& FORTUNA, T. (2006). Rheology of selected Polish honeys. $\begin{array}{llll}\text { Journal of Food } & \text { Engineering, } & 75(1), & 43-49\end{array}$ https://doi.org/10.1016/j.jfoodeng.2005.03.049

Kačániová, M., Hleba, L., Džugan, M., Pasternakiewicz, A., Kňazovická, V., Pavelková, A., ... Grabek-Lejko, D. (2012). Microbiological properties and antimicrobial effect of Slovakian and Polish honey having regard to the water activity and water content. Journal of Microbiology, Biotechnology and Food Sciences, 2(1), 272-281.

Kačániová, M., Sudzina, M., Sudzinová, J., Fikselová, M., Čuboň, J., \& Haščík P. (2007). Microbiological and physico - chemical quality of honey collected from different Slovak habitats. Slovak Journal of Animal Science, 40(1), 38 - 43. Kesic, A., Mazalovic, M., Crnkic, A., Catovic, B., Hadzidedic, S., \& Dragosevic, G. (2009). The Influence of L-Ascorbic Acid Content on Total Antioxidant Activity of Bee-Honey. European Journal of Scientific Research, 32, 95-101.

Lazaridou, A., Biliaderis, C.G., Bacandritsos, N., \& Sabatini, A. G. (2004)

Composition, thermal and rheological behaviour of selected Greek honeys. $\begin{array}{llll}\text { Journal of Food } & \text { Engineering, }\end{array}$ https://doi.org/10.1016/j.jfoodeng.2003.09.007

Mellen, M., Fikselová, M., Mendelová, A., \& Haščík, P. (2015). Antioxidan Effect of Natural Honeys Affected by Their Source and Origin. Polish Journal of Food and Nutritional Science, 65(2), 81-85. https://doi.org/10.1515/pjfns-2015$\underline{0020}$

Nurhadi, B., Andoyo, R., \& Mahani, I. R. (2012). Study the properties of honey powder produced from spray drying and vacuum drying method. International Food Research Journal, 19(3), 907-912.

Patel, R. P., Patel, M. P., \& Suthar, A. M. (2009). Spray drying technology: an overview. Indian Journal of Science and Technology, 2(10), 44-47. https://doi.org/10.17485/ijst/2009/v2i10/30719

PN-EN ISO 18125:2017-07, 2017. Solid biofuels - Determination of calorific value. Geneva : International Organization for Standardization.

Ram, K. A. (2011). Production of spray-dried honey powder and its application in bread. A Thesis The Department of Food Science Vellore Institute of Technology Available

on: https://digitalcommons.lsu.edu/cgi/viewcontent.cgi?referer=https://www.google. $\mathrm{pl} / \&$ httpsredir $=1 \&$ article $=2742 \&$ context=gradschool theses access: 10.15 .2018 ). Rybak-Chmielewska, H. (2007). High performance liquid chromatography (HPLC) study of sugar composition in some kinds of natural honey and winter stores processed by bees from starch syrup. Journal of Apicultural Science, 51(1), 23-38

Samborska, K. (2017). Autoreferat z opisem osiągnięć naukowych związanych z postępowaniem habilitacyjnym (A summary of scientific achievements related to the habilitation procedure) (Available on: http://wnoz.sggw.pl/wpcontent/uploads/Samborska Zał2 Autoreferat.pdf, access: 21.10.2018)

Samborska, K., \& Bieńkowska, B. (2013). Physicochemical properties of spray dried honey preparations. Zeszyty Problemowe Postępów Nauk Rolniczych, 575, 91-105.

Samborska, K., \& Czelejewska, M. (2014). The influence of thermal treatment and spray drying on the physico-chemical properties of Polish honeys. Journal of Food Processing and Preservation, 38(1), 413-419. https://doi.org/10.1111/j.1745-4549.2012.00789.x

Samborska, K., Gajek, P., \& Kamińska-Dwórznicka, A. (2015). Spray Drying of Honey: The Effect of Drying Agents on Powder Properties. Polish. Journal of Food and Nutrition Science, 65(2), 109 - 118. https://doi.org/10.2478/pjfns2013-0012

Shi, Q., Fang, Z., \& Bhandari, B. (2013). Physicochemical properties of spray dried honey powder produced with whey protein isolate and maltodextrin as carrier agents. (Available on https://espace.curtin.edu.au/bitstream/handle/20.500.11937/16772/193016_19301 6.pdf?sequence $=2$, access: 18.10 .2018 )

Stagos, D., Soulitsiotis, N., Tsadila, C., Papaeconomou, S., Arvanitis, C. Ntontos, A., ... Mossialos, D. (2018). Antibacterial and antioxidant activity of different types of honey derived from Mount Olympus in Greece. International Journal of Molecular Medicine, 42, 726-734. https://doi.org/10.3892/ijmm.2018.3656

Szweda P. (2017). Antimicrobial Activity of Honey, In: Vagner Arnaut De Toledo (ed): Honey Analisys, IntechOpen. doi: https://doi.org/10.5772/63259.

Truong, V., Bhandari, B. R., \& Howes T. (2005). Optimization of co-current spray drying process of sugar-rich foods. Part I-Moisture and glass transition temperature profile during drying. Journal of Food Engineering, 71(1), 55-65 https://doi.org/10.1016/j.jfoodeng.2004.10.017

Wesołowska, M., \& Dżugan M. (2017). The use of Photochem device in evaluation of antioxidant activity of polish honey. Food Analytical Methods 10(5), 1568-1574. https://doi.org/10.1007/s12161-016-0715-Z

Wesołowska, M., Kačániová M., \& Dżugan M. (2014). The antioxidant properties and microbiological quality of Polish honeys. Journal of Microbiology, Biotechnology and Food Sciences, 3(5), 422-425. 